\section{DUX is a non-essential synchronizer of zygotic genome activation}

\author{
Alberto De laco, Sonia Verp, Sandra Offner and Didier Trono*
}

School of Life Sciences, Ecole Polytechnique Fédérale de Lausanne (EPFL),

1015 Lausanne, Switzerland

${ }^{\star}$ Correspondence to:

Didier Trono

School of Life Sciences

Ecole Polytechnique Fédérale de Lausanne (EPFL)

1015 Lausanne, Switzerland

Email: didier.trono@epfl.ch 


\section{Summary statement (15-30 words)}

20 Murine DUX regulates transcription in the first embryonic cell divisions but it's

21 not necessary for embryogenesis

\section{Abstract (180 words)}

24 Some of the earliest transcripts produced in fertilized human and mouse 25 oocytes code for DUX, a double homeodomain protein that promotes 26 embryonic genome activation (EGA). Deleting Dux by genome editing at the

27 1- to 2-cell stage in the mouse impairs EGA and blastocyst maturation. Here, 28 we demonstrate that mice carrying homozygous Dux deletions display 29 markedly reduced expression of DUX target genes and defects in both pre30 and post-implantation development, with notably a disruption of the pace of

31 the first few cell divisions and significant rates of late embryonic mortality.

32 However, some Dux ${ }^{-/-}$embryos give raise to viable pups, indicating that DUX 33 is important but not strictly essential for embryogenesis. 


\section{Introduction}

36 Fertilization of the vertebrate oocyte is followed by transcription of the parental

37 genomes, a process known as zygotic or embryonic genome activation (ZGA

38 or EGA) (Jukam et al., 2017). In zebrafish and Drosophila, maternally

39 inherited transcription factors are responsible for this event (Lee et al., 2013;

40 Liang et al., 2008), while in placental mammals the EGA transcriptional

41 program is directly activated at or after the 2-cell (2C) stage by a family of

42 transcription factors expressed after fertilization, the DUX proteins (De laco et 43 al., 2017; Hendrickson et al., 2017; Whiddon et al., 2017). Recent studies 44 suggest that DPPA2 and DPPA4 are maternal factors responsible in the 45 mouse for DUX and downstream targets activation, although this model still 46 needs to be validated in vivo (De laco et al., 2018; Eckersley-Maslin et al., 47 2019). Forced expression of DUX proteins in murine or human cell lines 48 triggers the aberrant activation of EGA-restricted genes. Conversely, deleting 49 Dux by CRISPR-mediated genome editing before the 2-cell stage in murine 50 embryos leads to reduced expression of DUX targets such as MERVL and 51 Zscan4 and severe defects in early development, with many embryos failing 52 to reach the morula/blastocyst stage (De laco et al., 2017). However, this 53 procedure also yields some viable mice carrying heterozygous Dux deletions.

54 Here, we demonstrate that crossing these Dux ${ }^{+-}$animals results in Dux ${ }^{-/-}$ 55 embryos with impaired EGA and severe but not uniformly fatal defects in early 56 development. 
bioRxiv preprint doi: https://doi.org/10.1101/569434; this version posted March 6, 2019. The copyright holder for this preprint (which was not certified by peer review) is the author/funder, who has granted bioRxiv a license to display the preprint in perpetuity. It is made available under aCC-BY-NC-ND 4.0 International license.

59 The murine Dux gene is found in tandem repeats of variable lengths in so60 called macrosatellite repeats (Leidenroth et al., 2012). We injected zygotes

61 collected from B6D2F1 mothers with sgRNAs directed at sequences flanking 62 the Dux locus (Figure $1 \mathrm{AB}$ ), and transferred the resulting products into 63 pseudo-pregnant B6CBA mothers. One out of 42 pups carried a mono-allelic 64 deletion of the targeted region $\left(D u x^{+/}\right)$. This animal was backcrossed twice with wild-type (WT) B6D2F1 mice to ensure germline transmission of the mutation. The resulting $D u x^{+/-}$mice were healthy and did not display any macroscopic phenotype.

Transcription of Dux normally starts in zygotes just after fertilization and stops a few hours later (De laco et al., 2017), suggesting that the presence of a functional Dux allele is not necessary in germ cells. In our previous work, we

71 demonstrated that inhibition of DUX expression in zygotes impairs early 72 embryonic development. To characterize further the role of DUX, Dux ${ }^{+/-}$mice 73 were crossed and the frequency of Dux mono- and bi-allelic deletions was 74 determined in the progeny (Table 1). There was only a minor deviation from a Mendelian distribution of these genotypes, with a slightly lower than expected 76 frequency of $D u x^{-/-}$pups. Furthermore, adult $D u x^{-/-}$mice were healthy and 77 had a normal lifespan. To ensure that Dux was not expressed from some 78 other genomic locus, the absence of its transcripts was verified in testis of 79 Dux ${ }^{-/}$mice, since this is the only adult tissue where these RNAs are 80 normally detected (Snider et al., 2010) (Figure 1C).

81 To explore further the role of DUX in pre-implantation embryos, we compared 82 the size of litters yielded by isogenic $D u x^{+/+}$or $D u x^{-/-}$crossings (Table 2, 
83 Figure 1D). Crosses between $D u x^{-/-}$mice led to strong reductions in litter

84 size and delayed delivery, and some of the rare pups were eaten by their

85 mother after delivery, probably because they were either stillborn or exhibited physical impairments. Furthermore, some $D u x^{-/-}$females failed to give any pup, even when crossed with $D u x^{-/-}$males that had previously demonstrated their fertility when bred with other Dux ${ }^{-/-}$females (not illustrated). However, these apparently sterile $D u x^{-/-}$females produced litters of normal size

90 following crosses with wild type males (Figure 1E).

91 We then analyzed whether the strong lethality observed after $\left(D u x^{-/-} \times D^{-/-}\right)$

92 crosses occurred before or after implantation. For this, we repeated isogenic 93 crosses of WT or Dux ${ }^{-/-}$mice, retrieved the zygotes at embryonic day 0.5 94 (E0.5, 27 embryos from 3 (WT $x$ WT) and 42 embryos from $5\left(D^{-1-} \times x^{-1} x^{-/-}\right)$ 95 crosses), and monitored their ex vivo development for 4 days (Figure 2A). We 96 found that up to E1.5 Dux ${ }^{-/}$embryos divided faster that their WT 97 counterparts yet sometimes unevenly, with formation of 3-cell (3C) structures. At E2.0, WT embryos caught up whereas Dux ${ }^{-1-}$ embryos seemed partially blocked, to exhibit a clear delay at E3.5 with significantly reduced blastocyst

100 formation. By E4.5, only $65 \% D u x^{-/-}$embryos reached the blastocyst stage, 101 compared with $100 \%$ for WT. Confirming these findings, examination of E3.5 102 embryos from (WT $\times$ WT) or $\left(D u x^{-/-} \times D u x^{-/-}\right)$crosses revealed a strong delay 103 in blastocyst formation and increased levels of lethality in the absence of DUX 104 (Fig. 2BC). Finally, examining the uterus of $D u x^{-/-}$females previously found 105 to be sterile 18.5 days after crosses with $D u x^{-/-}$males revealed a significant 106 number of macroscopically normal embryos, suggesting that their apparent 
bioRxiv preprint doi: https://doi.org/10.1101/569434; this version posted March 6, 2019. The copyright holder for this preprint (which was not certified by peer review) is the author/funder, who has granted bioRxiv a license to display the preprint in perpetuity. It is made available under aCC-BY-NC-ND 4.0 International license.

107 sterility was partly due to perinatal mortality (Figure 2D). In conclusion, a

108 subset of embryos derived from $D u x^{-/-}$crosses fail to implant, while the rest 109 generally dies around birth.

110 Finally, we tested the consequences of zygotic DUX on the transcriptional

111 program of 2C-stage embryos. We collected 17 zygotes from three

112 heterozygous $\mathrm{Dux}^{+/-} \times \mathrm{xux}^{+/-}$crosses, incubated them in vitro and collected

113 RNA 5 hours after the formation of $2 \mathrm{C}$ embryos (Figure $3 \mathrm{~A}$ ). Three of these

114 contained undetectable levels of Dux transcripts, indicating that they most

115 likely were $D u x^{-/-}$, and an additional 3 displayed decreased levels of this RNA

116 compared to the other 11. Interestingly, all 6 Dux RNA-depleted 2C embryos

117 exhibited significant reductions in the expression of some (MERVL, Zscan4,

118 Eif1a, Usp17la, B020004J07Rik, Tdpoz4 and Cml2), but not all (Duxbl, Sp110,

119 Zfp352) genes previously suggested to represent DUX targets (De laco et al., 120 2017). We then bred 2 WT and $3 D u x^{-/-}$females with males from the same 121 genetic background, and compared transcription of putative DUX target genes 122 in the resulting $2 \mathrm{C}$ embryos. Products of the Dux ${ }^{-/-} \times \mathrm{Dux}^{-/-}$crosses 123 displayed a clear decrease in the expression of a subset of candidate DUX 124 targets (MERVL, Zscan4, Eif1a, Usp17la, B020004J07Rik), while others 125 (Tdpoz4, Cml2, Duxbl, Sp110, Zfp352) were again unaffected.

126 In sum, the present work confirms that DUX promotes murine embryonic 127 development. In spite of also surprisingly demonstrating that this factor is not 128 absolutely essential for this process, it further reveals that DUX depletion 129 results in a variable combination of pre- and post-implantation defects, the 130 consequences of which additionally appear cumulative over generations. 
bioRxiv preprint doi: https://doi.org/10.1101/569434; this version posted March 6, 2019. The copyright holder for this preprint (which was not certified by peer review) is the author/funder, who has granted bioRxiv a license to display the preprint in perpetuity. It is made available under aCC-BY-NC-ND 4.0 International license.

131 DUX-devoid embryos displayed deregulations in the timing and the ordinance

132 of the first few cell divisions, various degrees of impairments in their ability to

133 become blastocysts, and for those reaching that stage high levels of perinatal

134 mortality. Nevertheless, these defects became truly apparent only at the

135 second round of DUX-devoid embryogenesis, since the frequency of Dux ${ }^{-/-}$

136 pups derived from the crossing of heterozygous $D u x^{+/-}$parents was only

137 slightly below a Mendelian distribution whereas the resulting $D u x^{-/}$females

138 yielded markedly reduced progenies, some even appearing sterile when

139 crossed with Dux ${ }^{--}$males. However, this defect was completely rescued by

140 zygotic expression of Dux, since breeding these $D u x^{-/}$females with WT males

141 resulted in the production of normal size litters of pups devoid of obvious

142 defects. Thus, the presence of DUX during only a few hours after fertilization

143 appears to condition not only the conduct of the first few embryonic cell

144 divisions, but also to bear consequences that extend well beyond the pre-

145 implantation period, long after Dux transcripts have become undetectable.

146 Deleting the Dux inducers Dppa2 or Dppa4 also results in perinatal lethality

147 (Madan et al., 2009; Nakamura et al., 2011), but in this case defects in lung

148 and skeletal development are observed, which correlate with the expression

149 of these two genes later in embryogenesis. Future studies should therefore

150 attempt to characterize better the molecular defects induced by DUX depletion,

151 to explain how the full impact of the Dux KO phenotype is only expressed at

152 the second generation, and how even at that point it can be fully rescued by

153 paternally-encoded Dux zygotic expression. 
bioRxiv preprint doi: https://doi.org/10.1101/569434; this version posted March 6, 2019. The copyright holder for this preprint (which was not certified by peer review) is the author/funder, who has granted bioRxiv a license to display the preprint in perpetuity. It is made available under aCC-BY-NC-ND 4.0 International license.

\section{Material and Methods}

157 Plasmids

158 Two single guide RNAs (sgRNAs) targeting sequences flanking the Dux

159 macrosatellite repeat (Figure 1A) were cloned into px330 using a standard 160 protocol. The primers used to clone the sgRNAs are previously described (De 161 laco et al., 2017).

Generation of transgenic mice carrying Dux ${ }^{-1-}$ alleles

164 Pronuclear injection was performed according to the standard protocol of the

165 Transgenic Core Facility of EPFL. In summary, B6D2F1 mice were used as 166 egg donors (6 weeks old). Mice were injected with PMSG (10 IU), and HCG 167 (10 IU) 48 hours after. After mating females with B6D2F1 males, zygotes 168 were collected and kept in KSOM medium pre-gassed in $5 \% \mathrm{CO} 2$ at $37^{\circ} \mathrm{C}$.

169 Embryos were then transferred to M2 medium and microinjected with 10 $170 \mathrm{ng} / \mu \mathrm{g}$ of px330 plasmids encoding for Cas9 and the appropriate sgRNAs 171 diluted in injection buffer (10mM Tris $\mathrm{HCl}$ pH7.5, 0.1mM EDTA pH8, 100mM $172 \mathrm{NaCl})$. After microinjection, embryos were reimplanted in pseudopregnant 173 B6CBA mothers. The pups delivered were genotyped for Dux null alleles 174 using previously described primers (De laco et al., 2017). The mouse carrying 175 the Dux null allele was then bred with B6D2F1 mice to ensure that the

176 transgenic allele reached germ line and to dilute out any randomly integrated

177 Cas9 transgene. This process was repeated once again to obtain second filial 178 generation (F2) Dux ${ }^{-/+}$mice. 
bioRxiv preprint doi: https://doi.org/10.1101/569434; this version posted March 6, 2019. The copyright holder for this preprint (which was

not certified by peer review) is the author/funder, who has granted bioRxiv a license to display the preprint in perpetuity. It is made available under aCC-BY-NC-ND 4.0 International license.

Monitoring of pre-implantation embryos

181 Zygotes were collected and cultured in $\mathrm{KSOM}$ medium at $37^{\circ} \mathrm{C}$ in $5 \% \mathrm{CO} 2$ for

1824 days. Each embryo was monitored every 12 hours to determine the stage of 183 development.

184 Randomization and blind outcome assessment were not applied. All animal experiments were approved by the local veterinary office and carried out in 186 accordance with the EU Directive (2010/63/ EU) for the care and use of laboratory animals.

Standard PCR, RT-PCR and RNA sequencing

For genotyping the Dux null allele, genomic DNA was extracted with DNeasy

191 Blood \& Tissue Kits (QIAGEN) and the specific PCR products were amplified 192 using PCR Master Mix 2X (Thermo Scientific) combined with the appropriate 193 primers (design in Figure 1A) (De laco et al., 2017). Ambion Single Cell-to-CT 194 kit (Thermo Fisher) was used for RNA extraction, cDNA conversion and mRNA pre-amplification of $2 \mathrm{C}$ stage embryos. Primers (previously listed) were used for SYBR green qPCR (Applied Biosystems) (De laco et al., 2017).

\section{Acknowledgements}

199 We thank the Transgenic Core Facility of EPFL for technical assistance. This 200 work was financed through grants from the Swiss National Science 201 Foundation, the Gebert-Rüf Foundation, FP7 MC-ITN INGENIUM (290123), 202 and the European Research Council (ERC 694658) to D.T. 
bioRxiv preprint doi: https://doi.org/10.1101/569434; this version posted March 6, 2019. The copyright holder for this preprint (which was

not certified by peer review) is the author/funder, who has granted bioRxiv a license to display the preprint in perpetuity. It is made available under aCC-BY-NC-ND 4.0 International license.

De laco et al., page

10

203

204 Author contributions

205 A.D.I and D.T. conceived the project and wrote the manuscript. A.D.I., S.V.,

206 S.O. designed the experiments, carried out the experiments and analyzed the 207 data.

208

209 Conflict of interest

210 The authors declare that they have no conflict of interest.

211

212 
References

214

215
De Iaco, A., Couderay, A., Duc, J. and Trono, D. (2018). DPPA2 and DPPA4 are necessary to establish a totipotent state in mouse embryonic stem cells. bioRxiv.

De Iaco, A., Planet, E., Coluccio, A., Verp, S., Duc, J. and Trono, D. (2017). DUXfamily transcription factors regulate zygotic genome activation in placental mammals. Nature genetics 49, 941-945.

Eckersley-Maslin, M., Alda-Catalinas, C., Blotenburg, M., Kreibich, E., Krueger, C. and Reik, W. (2019). Dppa2 and Dppa4 directly regulate the Dux-driven zygotic transcriptional program. Genes \& development 33, 194-208.

Hendrickson, P. G., Dorais, J. A., Grow, E. J., Whiddon, J. L., Lim, J. W., Wike, C. L., Weaver, B. D., Pflueger, C., Emery, B. R., Wilcox, A. L., et al. (2017). Conserved roles of mouse DUX and human DUX4 in activating cleavagestage genes and MERVL/HERVL retrotransposons. Nature genetics $\mathbf{4 9}$, 925-934.

Jukam, D., Shariati, S. A. M. and Skotheim, J. M. (2017). Zygotic Genome Activation in Vertebrates. Developmental cell 42, 316-332.

Lee, M. T., Bonneau, A. R., Takacs, C. M., Bazzini, A. A., DiVito, K. R., Fleming, E. S. and Giraldez, A. J. (2013). Nanog, Pou5f1 and SoxB1 activate zygotic gene expression during the maternal-to-zygotic transition. Nature 503, 360-364.

Leidenroth, A., Clapp, J., Mitchell, L. M., Coneyworth, D., Dearden, F. L., Iannuzzi, L. and Hewitt, J. E. (2012). Evolution of DUX gene macrosatellites in placental mammals. Chromosoma 121, 489-497.

Liang, H. L., Nien, C. Y., Liu, H. Y., Metzstein, M. M., Kirov, N. and Rushlow, C. (2008). The zinc-finger protein Zelda is a key activator of the early zygotic genome in Drosophila. Nature 456, 400-403.

Madan, B., Madan, V., Weber, O., Tropel, P., Blum, C., Kieffer, E., Viville, S. and Fehling, H. J. (2009). The pluripotency-associated gene Dppa4 is dispensable for embryonic stem cell identity and germ cell development but essential for embryogenesis. Mol Cell Biol 29, 3186-3203.

Nakamura, T., Nakagawa, M., Ichisaka, T., Shiota, A. and Yamanaka, S. (2011). Essential roles of ECAT15-2/Dppa2 in functional lung development. Mol Cell Biol 31, 4366-4378.

Snider, L., Geng, L. N., Lemmers, R. J., Kyba, M., Ware, C. B., Nelson, A. M., Tawil, R., Filippova, G. N., van der Maarel, S. M., Tapscott, S. J., et al. (2010). Facioscapulohumeral dystrophy: incomplete suppression of a retrotransposed gene. PLoS genetics 6, e1001181.

Whiddon, J. L., Langford, A. T., Wong, C. J., Zhong, J. W. and Tapscott, S. J. (2017). Conservation and innovation in the DUX4-family gene network. Nature genetics 49, 935-940. 


\section{Figure Legends}

Figure 1. DUX promotes embryonic development but is not necessary

260 for it

261 (A) Schematics of CRISPR/Cas9 depletion of Dux alleles. Single guide RNAs

262 (sgRNA) targeting the flanking region of the Dux repeat recruit Cas9

263 nucleases for the excision of the allele. Dux and Gm4981 are two isoforms of

264 the Dux gene repeated in tandem in the Dux locus. Smpdl3a and Gcc2 are

265 the genes flanking the Dux locus. (B) Generation of Dux ${ }^{-l-}$ transgenic mice.

266 Zygotes were injected in the pronucleus with plasmids encoding for Cas9

267 nuclease and the specific sgRNAs, transferred to a pseudopregnant mother

268 and the transgenic pups were finally screened for the null alleles. (C)

269 Expression of Dux in testes from adult Dux ${ }^{+/+}$and Dux ${ }^{-/-}$mice. (D) WT or

270 Dux KO parents were crossed and litter size was quantified. (E) Dux ${ }^{-/-}$

271 females were crossed with $D u x^{-/-}$or $D u x^{+/+}$males and litter size was 272 quantified.

Figure 2. Dux promotes both pre- and post-implantation development

275 (A) Zygotes from $D u x^{+/+}(n=3)$ or $\operatorname{Dux}^{-/-}(\mathrm{n}=5)$ parents were monitored

276 every 12 hours for their ability to differentiate ex vivo from embryonic day 1.5

277 (E1.5) to 4.5 (E4.5). Average percent of $D u x^{+/+}(n=27)$ or Dux ${ }^{-/-}(n=42)$

278 embryos reaching a specific embryonic stage at each time point is 279 represented. E3.5 embryos from WT $(n=30)$ or Dux KO $(n=28)$ parents 280 were collected. (B) Average percent of embryos reaching the late blastocyst 281 stages (white) or failing to differentiate (delayed embryos, grey; dead embryos, 
bioRxiv preprint doi: https://doi.org/10.1101/569434; this version posted March 6, 2019. The copyright holder for this preprint (which was

not certified by peer review) is the author/funder, who has granted bioRxiv a license to display the preprint in perpetuity. It is made available under aCC-BY-NC-ND 4.0 International license.

black) was quantified. (C) Bright-field images of the E3.5 embryos. (D) Dux ${ }^{-/-}$ males and females were bred and number of born pups was quantified. The

284 same animals were bred again and embryos were quantified at E18.5.

Figure 3. A subset of ZGA-specific genes is not expressed in $2 \mathrm{C}$ in

\section{absence of DUX}

288 Comparative expression of Dux, early ZGA genes (Zscan4, Eif1a, Usp17la, 289 B020004J07Rik, Tdpoz4, Cml2, Duxbl, Sp110, Zfp352), a 2C-restricted TE 290 (MERVL), and Zbed3, a gene stably expressed during pre-implantation 291 embryonic development, in 2C stage embryos derived from (A) Dux ${ }^{+/}$ 292 breeding $(\mathrm{n}=4)$ or $(\mathrm{B}) \operatorname{Dux} \mathrm{x}^{+/+}(\mathrm{n}=2)$ and $D u x^{-/-}(\mathrm{n}=3)$ breeding. Green and 293 blue dots in $(A)$ represent the mRNA levels of embryos expressing high or low 294 levels of Dux respectively. Different shades of green or blue in (B) represent 295 embryos collected from different mothers (975 and 960 are Dux ${ }^{+/+}$mothers, 296965,992 and 994 are Dux ${ }^{-/-}$mothers). Expression was normalized to Zbed3. ${ }^{* *} p \leq 0.01,{ }^{* * *} p \leq 0.001, t$ test. 


\section{Table Legends}

300 Table 1 Genotype distribution from $\mathrm{Dux}^{+/-} \times \mathrm{Dux}^{+/-}$crosses

\begin{tabular}{|l|l|l|l|}
\hline Genotypes & Dux & Dux & Dux \\
\hline $\begin{array}{l}\text { Observed n. of pups } \\
\text { (expected n. of pups) }\end{array}$ & $\begin{array}{l}118 \\
(109)\end{array}$ & $\begin{array}{l}225 \\
(218)\end{array}$ & $\begin{array}{l}93 \\
(109)\end{array}$ \\
\hline
\end{tabular}

301

Table 2 Genotype distribution from $D u x^{+/+} \times D u x^{+/+}$and $D u x^{-/-} \times D u x^{-/-}$

crosses

\begin{tabular}{|l|l|l|}
\hline Crosses & Dux $^{+/+} \mathbf{x} \mathbf{D u x}^{+/+}$ & $\mathbf{D u x}^{-/-} \mathbf{x ~ D u x}^{-/-}$ \\
\hline Total n. pups (litters) & $55(6)$ & $36(17)$ \\
\hline Average litter size & 9.2 & 2.1 \\
\hline Day of delivery (embryonic days) * & 19.5 & 20.8 \\
\hline
\end{tabular}



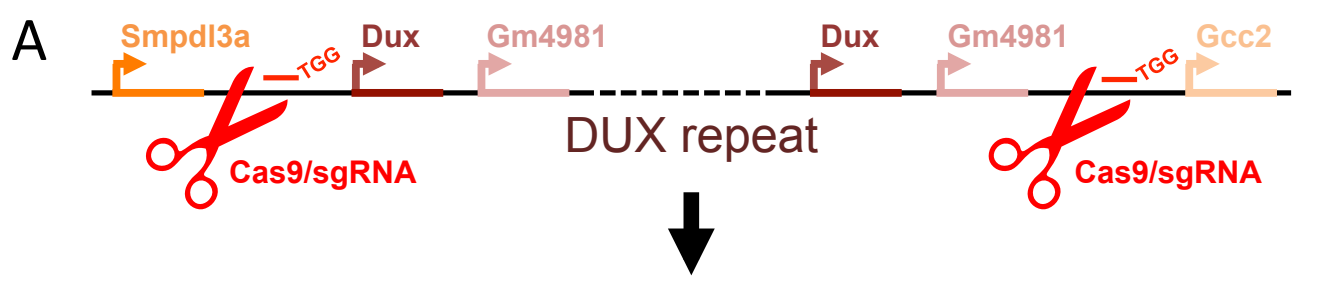

DUX+ allele

B

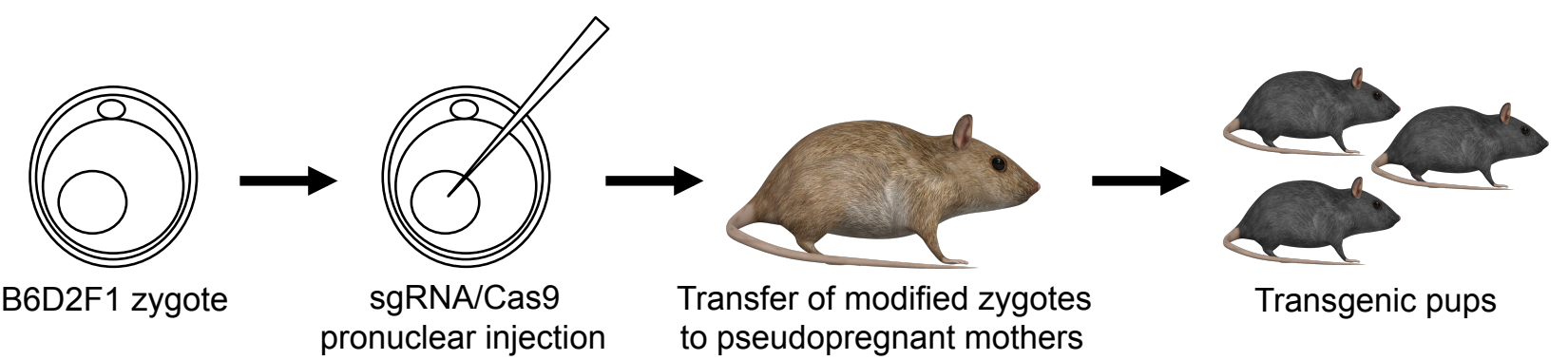

C

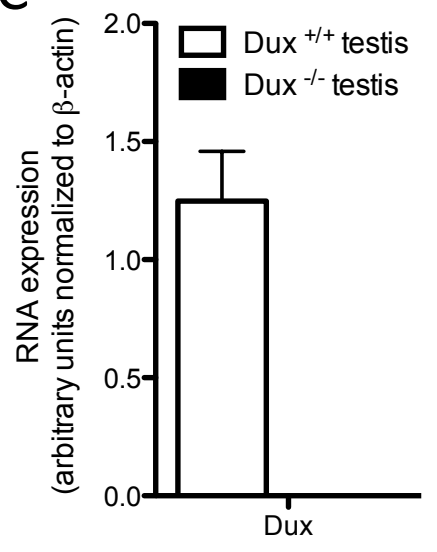

D

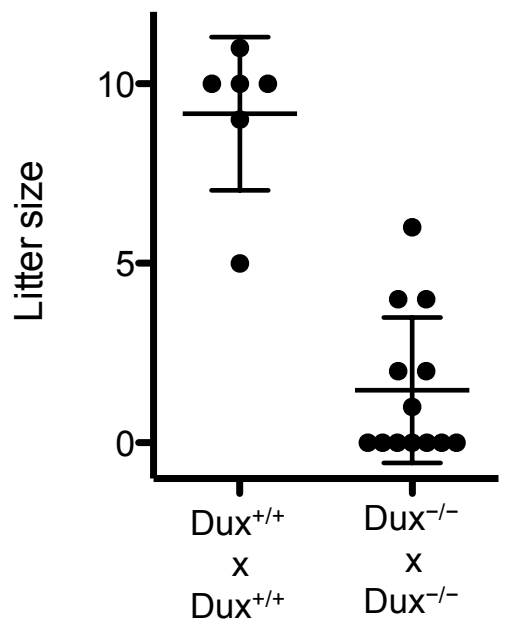

E

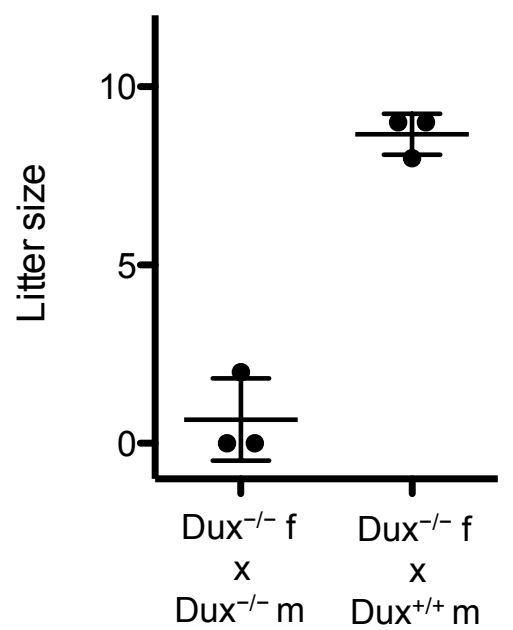



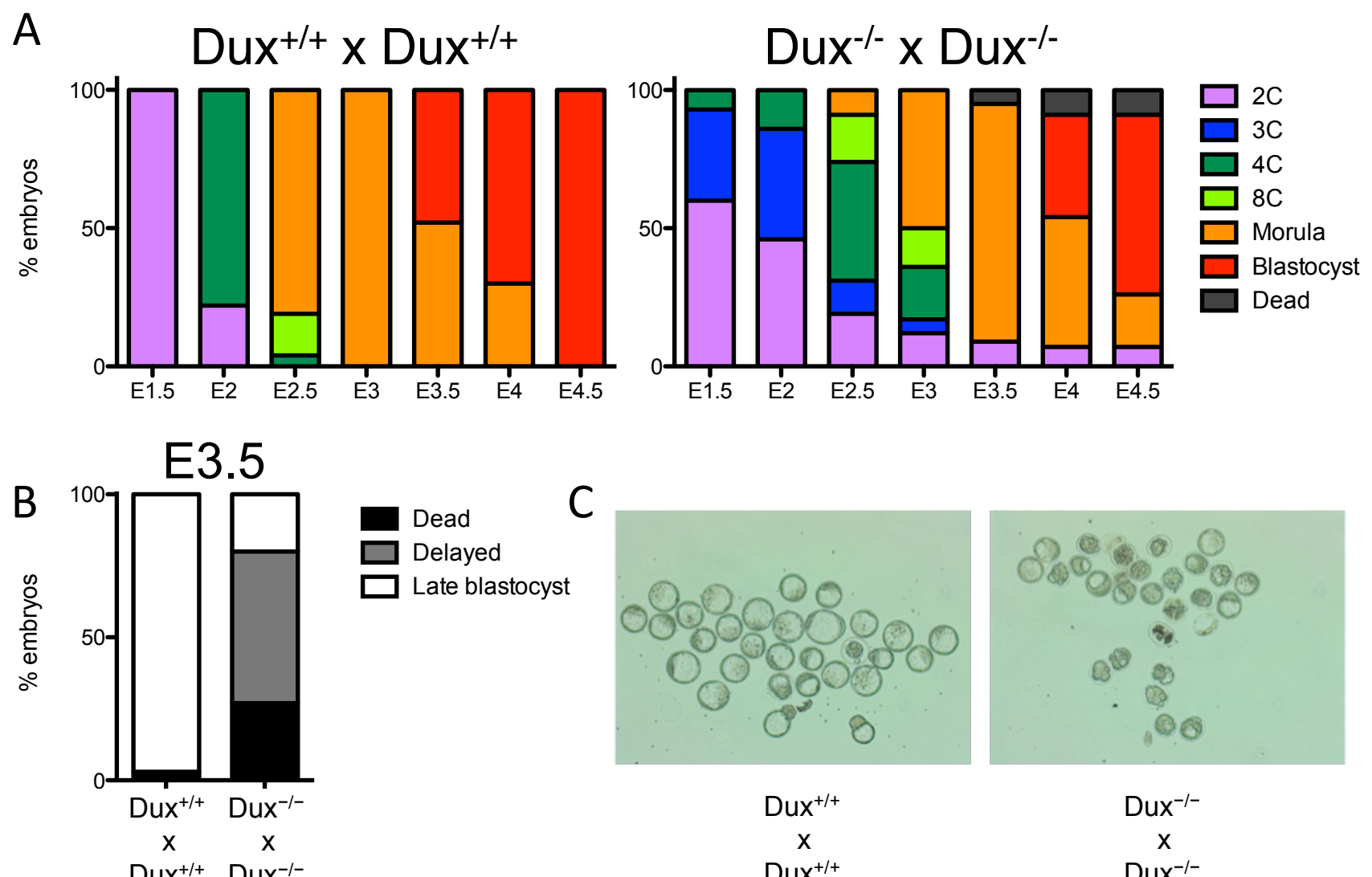

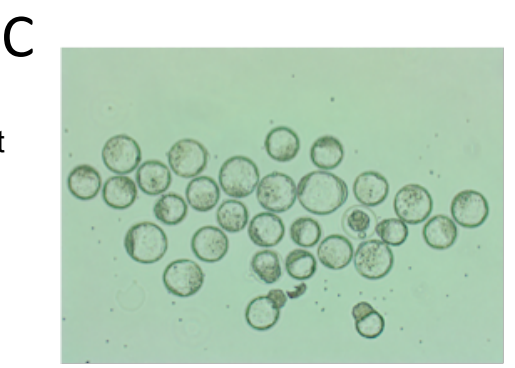

Dux ${ }^{+/+}$

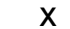

$\operatorname{Dux}^{+/+}$

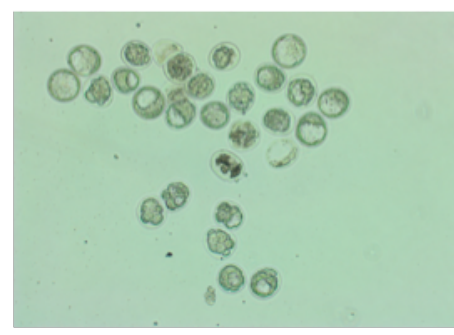

$\operatorname{Dux}^{-/-}$

$\mathrm{X}$

Dux ${ }^{-/-}$

D

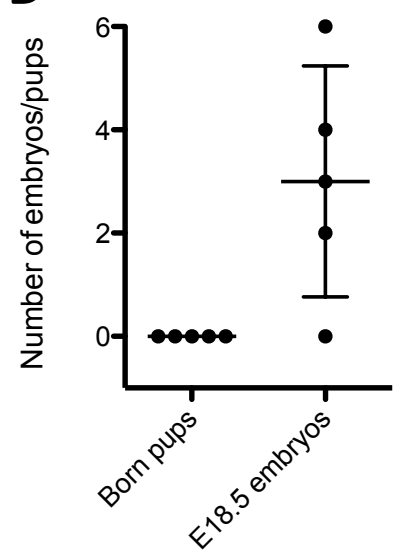


A

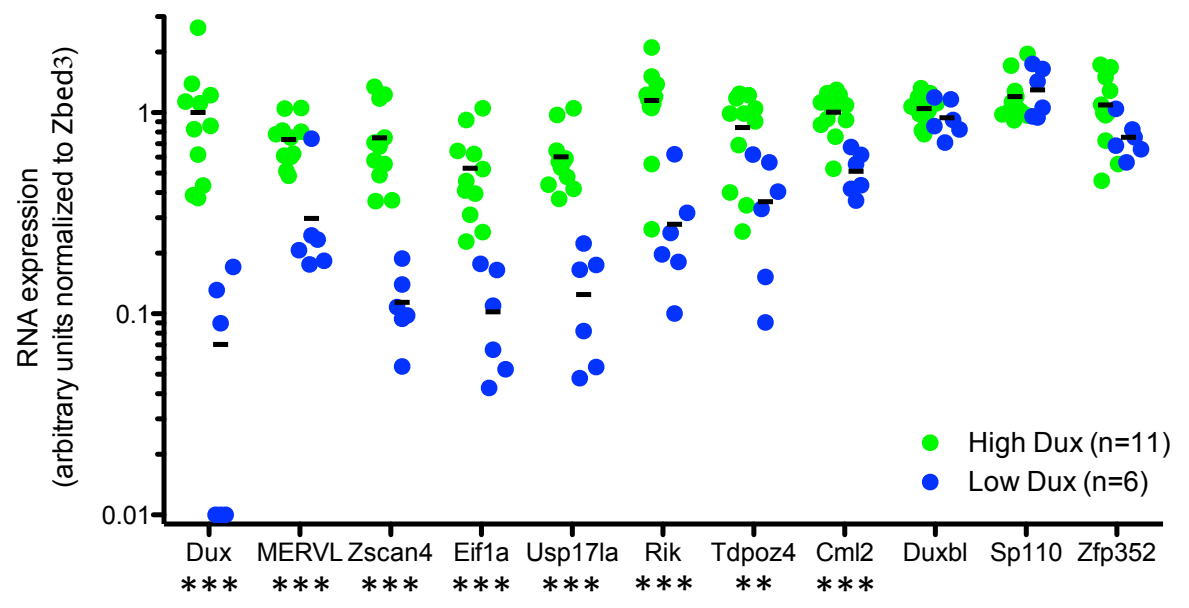

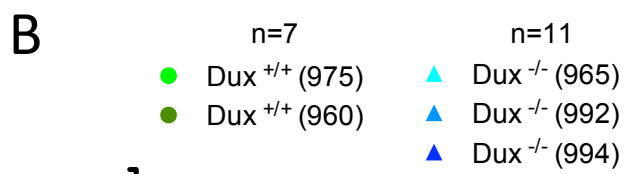

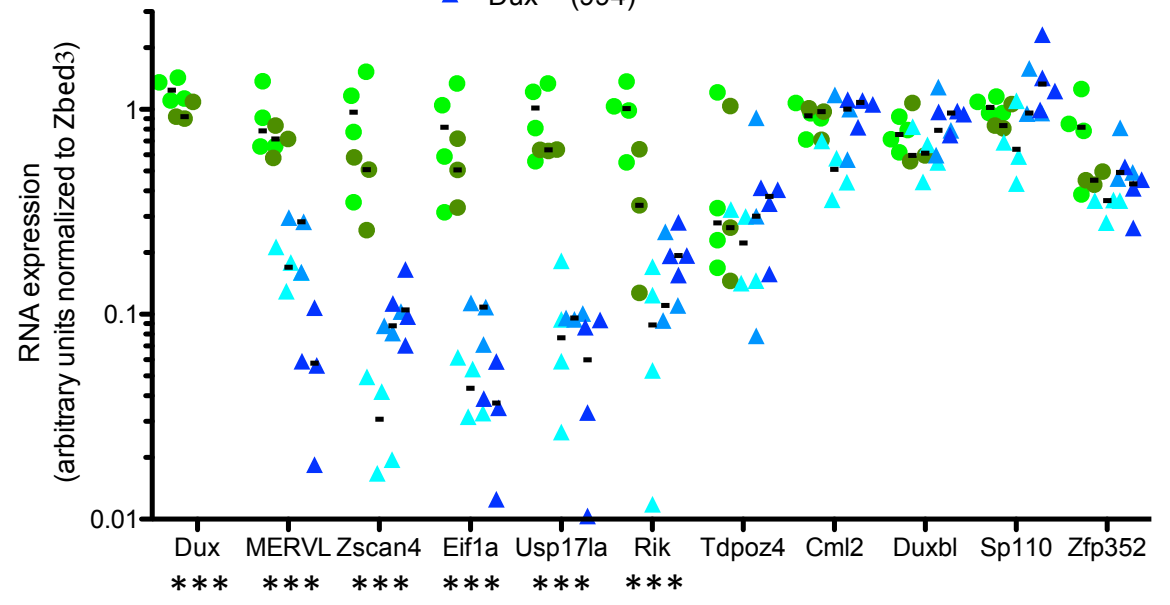

